University of Nebraska - Lincoln DigitalCommons@University of Nebraska - Lincoln

USGS Staff -- Published Research

US Geological Survey

1979

\title{
URANIUM TRANSPORT IN THE WALKER RIVER BASIN, CALIFORNIA AND NEVADA
}

Larry Benson

U.S. Geological Survey, great.basin666@gmail.com

D. L. Leach

U.S. Geological Survey

Follow this and additional works at: http://digitalcommons.unl.edu/usgsstaffpub

Part of the Geology Commons, Oceanography and Atmospheric Sciences and Meteorology Commons, Other Earth Sciences Commons, and the Other Environmental Sciences Commons

Benson, Larry and Leach, D. L., "URANIUM TRANSPORT IN THE WALKER RIVER BASIN, CALIFORNIA AND NEVADA" (1979). USGS Staff -- Published Research. 1001.

http://digitalcommons.unl.edu/usgsstaffpub/1001

This Article is brought to you for free and open access by the US Geological Survey at DigitalCommons@University of Nebraska - Lincoln. It has been accepted for inclusion in USGS Staff -- Published Research by an authorized administrator of DigitalCommons@University of Nebraska - Lincoln. 


\section{URANIUM TRANSPORT IN THE WALKER RIVER BASIN, CALIFORNIA AND NEVADA*}

\section{L.V. BENSON and D.L. LEACH}

Lawrence Berkeley Laboratory, University of California, Berkeley, Calif. (U.S.A.) U.S. Geological Survey, MS 973, Box 25046, Federal Center, Denver, Colo. 80225 (U.S.A.)

(Received December 5, 1978; revised and accepted February 5, 1979)

\section{ABSTRACT}

Benson, L.V. and Leach, D.L., 1979. Uranium transport in the Walker River Basin, California and Nevada. J. Geochem. Explor., 11: 227-248.

During the summer of 1976 waters from tributaries, rivers, springs and wells were sampled in the Walker River Basin. Snow and sediments from selected sites were also sampled. All samples were analyzed for uranium and other elements. The resulting data provide an understanding of the transport of uranium within a closed hydrologic basin as well as providing a basis for the design of geochemical reconnaissance studies for the Basin and Range Province of the Western United States.

Spring and tributary data are useful in locating areas containing anomalous concentrations of uranium. However, agricultural practices obscure the presence of known uranium deposits and render impossible the detection of other known deposits.

Uranium is extremely mobile in stream waters and does not appear to sorb or precipitate. Uranium has a long residence time (2500 years) in the open waters of Walker Lake; however, once it crosses the sediment-water interface, it is reduced to the U(IV) state and is lost from solution.

Over the past two million years the amount of uranium transported to the terminal point of the Walker River system may have been on the order of $4 \times 10^{8} \mathrm{~kg}$. This suggests that closed basin termini are sites for significant uranium accumulations and are, therefore, potential sites of uranium ore deposits.

\section{INTRODUCTION}

\section{Objectives.}

(1) To describe the processes which govern the transport of uranium in this environment.

(2) To evaluate the effectiveness of a widely-spaced water sampling network as a means of detecting known uranium anomalies.

(3) To describe the seasonal changes in uranium concentration.

(4) To evaluate the effects of mining and agricultural activities on the transport and distribution of uranium.

(5) To estimate the flux of uranium from the upper basin to the terminal point.

*Work performed under auspices of the U.S. Department of Energy by the Lawrence Livermore Laboratory under contract number W-7405-ENG-48. 
Geologic setting. The Walker River Basin, which lies in the western margin of the Basin and Range province, is located in west-central Nevada and adjacent areas of California (Fig. 1). East of the Sierra crest the region has an arid to semi-arid climate and a topography characterized by alternating elongate ranges and valleys. The western portion of the basin consists largely of quartz diorites, quartz monzonites, and granitic rocks of the Sierra Nevada. In the central and eastern portion of the basin, the rock types include Mesozoic metavolcanics and metasediments; Cretaceous granites, quartz monzonites, and granodiorites; and Tertiary volcanics and sediments as well as Tertiary to Recent alluvium. The geology of the Walker River Basin is described by Gilbert and Reynolds (1973), Moore (1969), and Ross (1961).

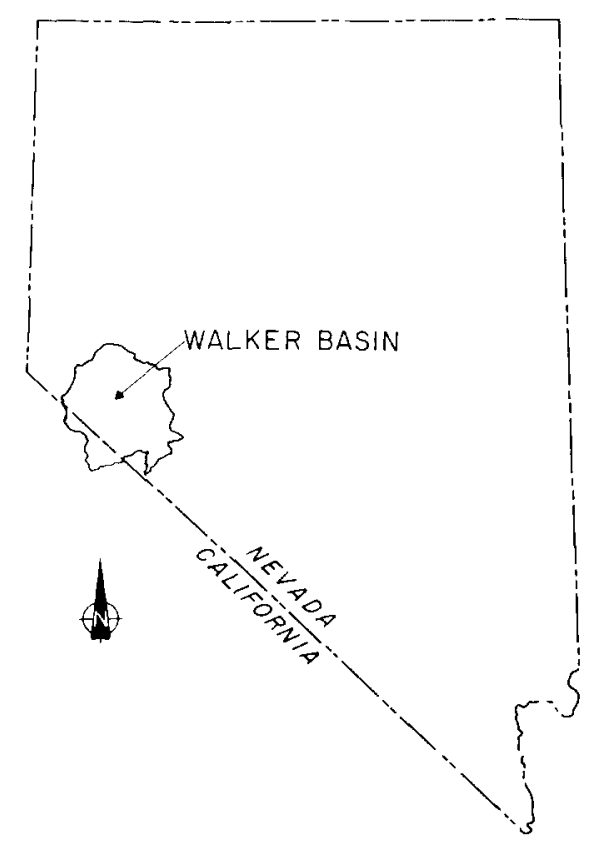

Fig. 1. Location of the Walker River Basin.

The hydrologic system. The $10,900 \mathrm{~km}^{2}$ basin is drained by the East and West Forks of the Walker River and by numerous small ephemeral tributaries (Fig. 2). The West Fork heads in California and flows north through Antelope, Smith and Mason Valleys, where it merges with the East Walker River which heads in the vicinity of Bridgeport, California. The Walker River then flows north $6 \mathrm{~km}$, turns to the southeast and terminates at Walker Lake. The entire drainage area forms a closed basin with no external outlet.

The major contributor to surface flow is snowmelt which, during April through August, accounts for approximately $80 \%$ of the annual surface water flow (Vasey and Hastings, 1974). 


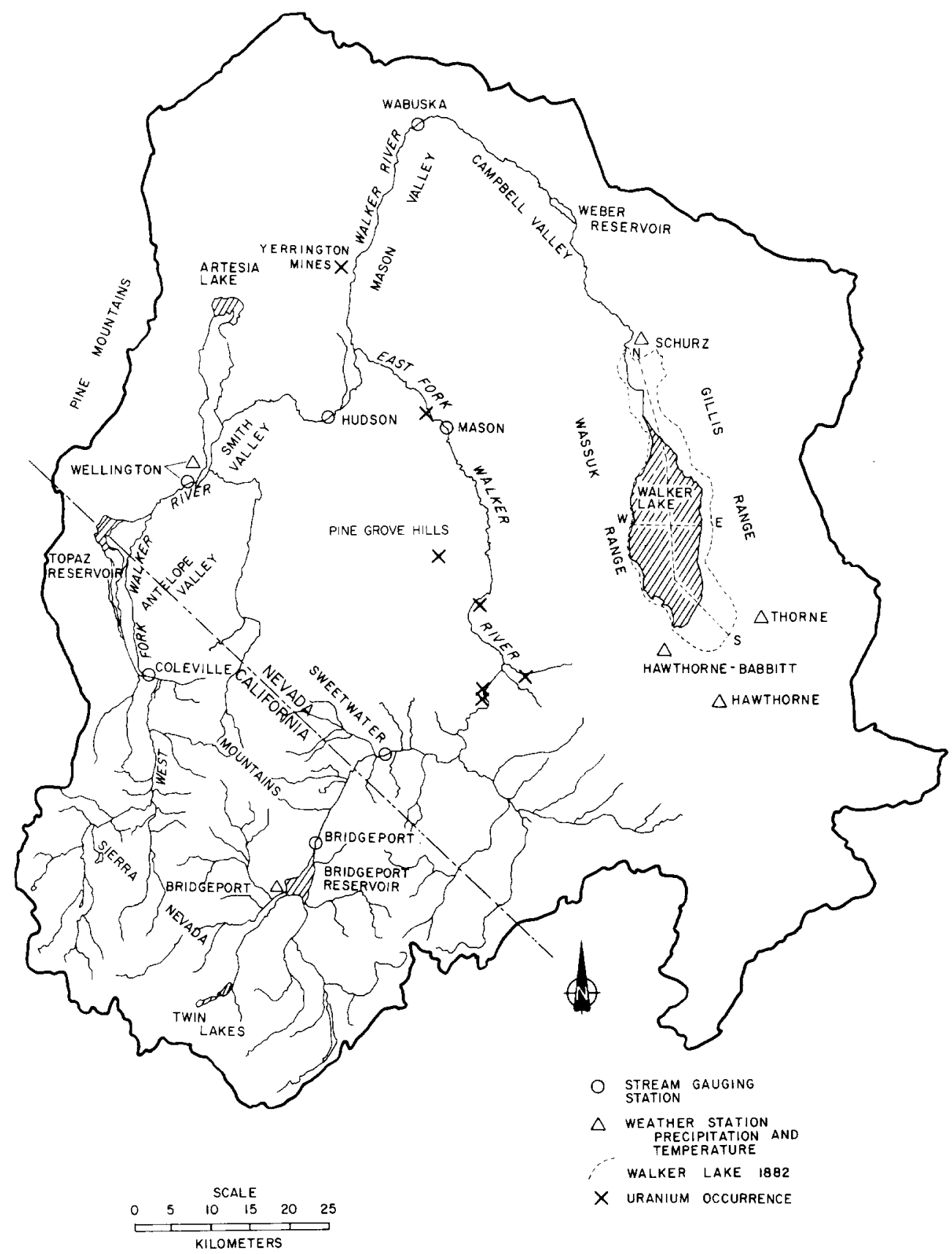

Fig. 2. Walker River drainage system. 


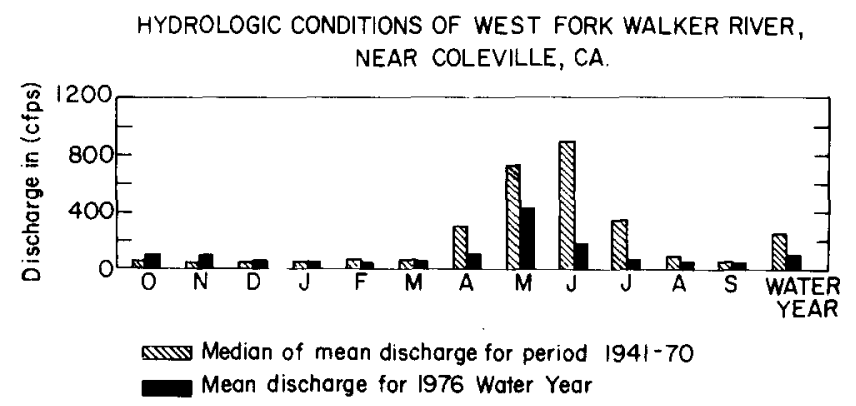

Fig. 3. Discharge data for the West Fork of the Walker River at Coleville, California.

To illustrate the effect of snowmelt on stream flow in the region, the discharge data for the West Fork of the Walker River at Coleville, California are presented in Fig. 3. Agricultural demands have led to flow regulation with the use of reservoirs such as Bridgeport and Topaz (Fig. 2); in addition, irrigation systems have been established in Bridgeport, Antelope, Smith and Mason Valleys. Synchronous discharge measurements on major gauging sites for the period 1958-1974 (Water Resources Data for Nevada Series) indicate that losses during this period averaged $230 \times 10^{6} \mathrm{~m}^{3} / \mathrm{yr}$, or $60 \%$ of the potential input to Walker Lake. The lake has decreased in depth by $50 \%$ and in volume by $67 \%$ since 1882 . If this water were restored to the system, the surface elevation of Walker Lake would stand at approximately $1250 \mathrm{~m}$ - about the 1882 level - which suggests that agricultural activities and not climatic fluctuations have caused the decline of Walker Lake.

Today irrigated lands total $484 \mathrm{~km}^{2}$ (Vasey and Hastings, 1974). Assuming an annual diversion requirement of $1.5 \mathrm{~m}^{3} /$ unit area (Domenico et al., 1966), $730 \times 10^{6} \mathrm{~m}^{3}$ of water is applied annually. Since, on the average, only $381 \times 10^{6} \mathrm{~m}^{3}$ of water is annually available within the entire surface flow system (Water Resources Data for Nevada Series), a significant recycling of water occurs. This results in an increase in the concentration and a change in the masses of dissolved solids carried by the Walker River.

Economic geology. An important consideration in selecting the Walker Basin for study was the presence of uraniferous deposits and prospects along the East Fork of the Walker River (Fig. 2). Staatz and Bauer (1953) described the occurrence of uraninite, kasolite, and various secondary uranium minerals in three closely related settings: (1) quartz veins in granitic rocks containing silver, lead, copper and iron sulfides; (2) altered granitic rocks adjacent to quartz veins; and (3) fault gouge zones. Garside (1973) also described several uranium occurrences in carbonaceous material in certain ash-flow tuffs.

Near Yerrington (Fig. 2), the Walker River flows within $300 \mathrm{~m}$ of one of Nevada's largest open pit copper mines and processing facilities. This provides a means to evaluate the possible effects of mining activities on geochemical reconnaissance. The sulfides in the ore deposit are largely pyrite 
and chalcopyrite. In addition, minor amounts of secondary uranium minerals have been reported (Garside, 1973).

Methods. Waters from newly fallen snow, tributaries, rivers, springs, wells and lakes (Fig. 4) were sampled in 1976 and analyzed for a variety of constituents (Table I). River waters were sampled twice: in June during high runoff and in August during low flow. Tributary waters, however, were sampled only during the high runoff regime. River sediments were also collected at 29 sites during the low flow regime. Each sampling was accomplished within a single day so that the chemistry of the water system was fixed with respect to time. The water samples were field-filtered $(0.45 \mu \mathrm{m})$ into polyethylene bottles, and samples for trace metal analyses were also fieldacidified to $\mathrm{pH} 1$ with high-purity $\mathrm{HNO}_{3}$. Uranium data were obtained by delayed neutron counting or by neutron activation and gamma counting. For samples having low concentrations of uranium ( $1 \mathrm{ppb})$, pre-concentration by evaporation was performed; and the detection limit for uranium in most waters, by this method, was $0.1 \mathrm{ppb}$.

\section{TABLE I}

Analytical methods

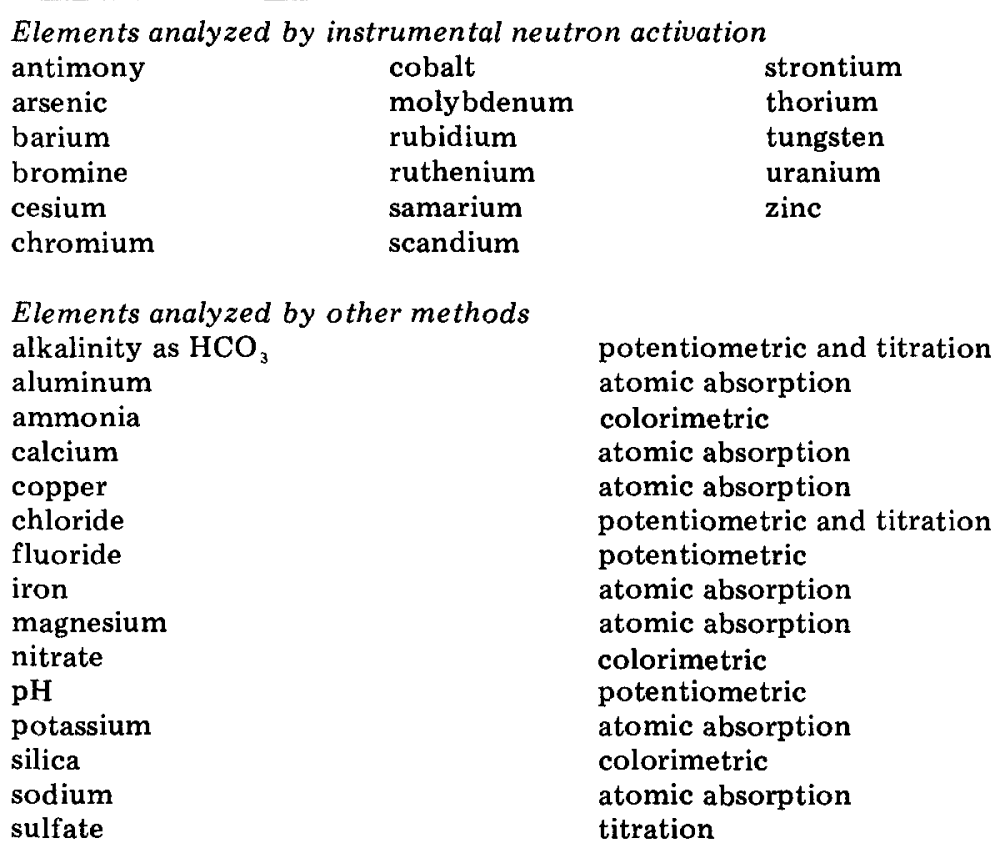




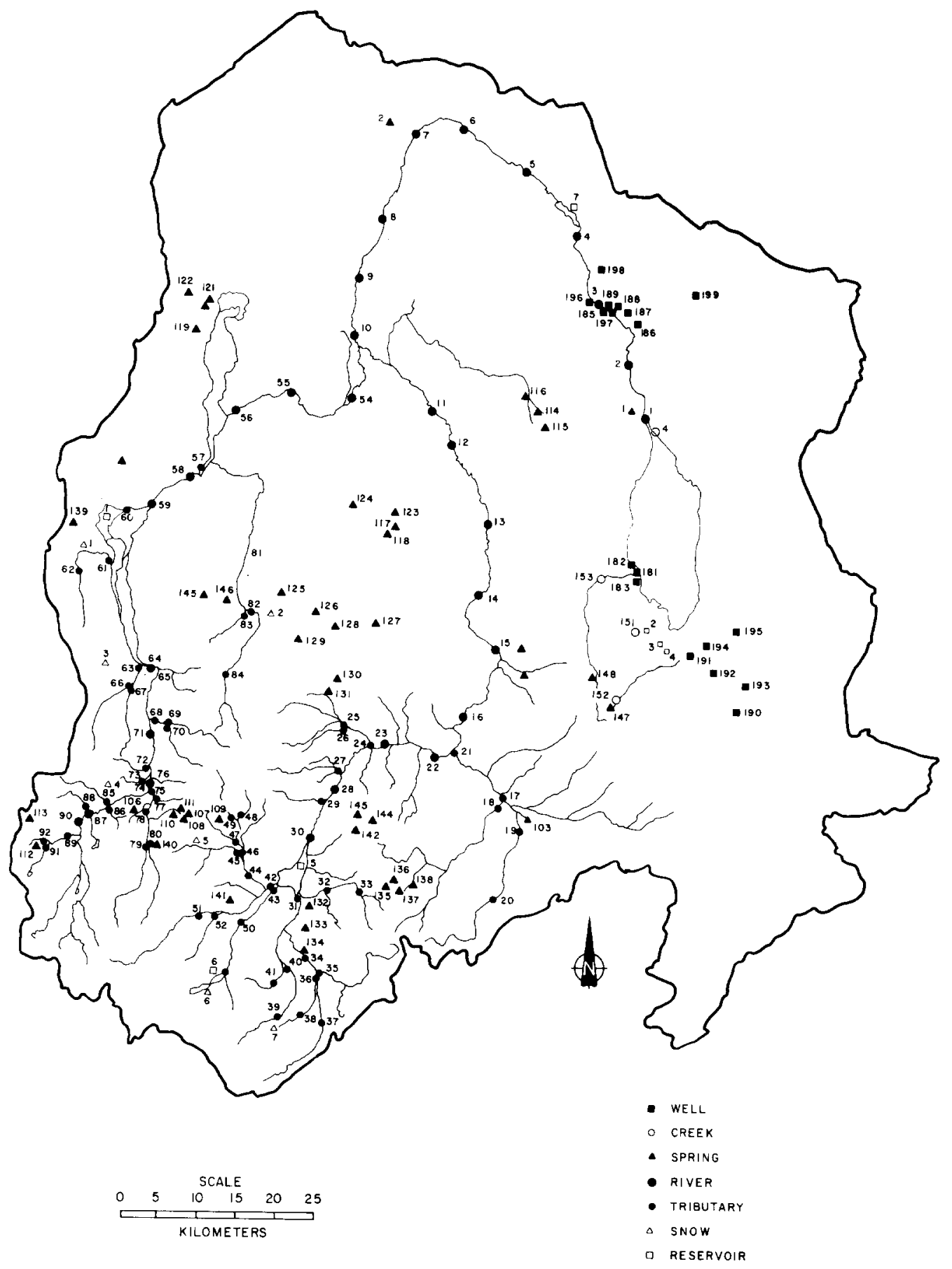

Fig. 4. Sample locations. 
Uranium in snow. Of 26 sites sampled for snow in the east-central Sierra Nevada by Brown and Skau (1975), ten samples were subsequently analyzed for uranium (Fig. 4). Only one sample contained detectable uranium (30 pptr), indicating the insignificant contribution of uranium via precipitation.

Uranium in spring waters. The concentration of uranium in spring water (Fig. 5) is typically low $(<0.5 \mathrm{ppb})$ and often not detectable in the headwaters region. An area of high-uranium springs, with concentrations of up to $124 \mathrm{ppb}$, was found in the center of the basin; however, no significant uranium anomalies in rocks of this area have been reported. The area of high uranium-bearing springs very nearly outlines a biotite-granite outcrop in the Pine Grove Hills. The springs appear to lie at the contact between granite and either andesite or sedimentary units.

Uranium in wells. Basin-wide sampling of wells was not attempted; only samples from wells located on the periphery of Walker Lake were analyzed. Uranium concentrations in these samples of fluids interstitial to former lake Lahontan sediments are relatively high.

Uranium in tributaries. With the onset of spring, snowmelt is released to the tributary system. Chemical reaction of the acidic snowmelt $(\mathrm{pH} \sim 5.6)$ with surficially exposed granite, granodiorite, and felsic volcanic rocks releases uranium to tributary waters.

In the Sierran headwater region, the concentration of uranium is typically less than $2 \mathrm{ppb}$ and often only a few tenths of a part per billion (Fig. 5). However, in one area in the west-central portion of the basin, concentrations in excess of $2 \mathrm{ppb}$ were found - one sample having a value of $58 \mathrm{ppb}$. Comparison of uranium and chloride concentrations were used to estimate possible concentration or dilution effects. This procedure assumes that chloride concentrations in the country rocks are approximately the same everywhere. Uranium/chloride ratios in the area having anomalous uranium concentrations are higher than in other areas of the headwater region, suggesting that the values are not related to concentration effects. Relatively high uranium concentration and high uranium/chloride ratios were also observed in the streams that drain directly into the western edge of Walker Lake (Fig. 5). None of these areas contains known uranium occurrences; however, both areas contain true granites, whereas in other areas granodiorites predominate.

Uranium in the East Fork. The East Fork of the Walker River flows through an area of known uranium occurrences showing only a minor downstream increase in uranium concentration (Figs. 2 and 6). During the high-flow regime (June), uranium increases from 1.3 to $1.9 \mathrm{ppb}$; and during the lowflow regime uranium increases from 1.5 to $1.9 \mathrm{ppb}$. This gradual downstream increase in concentration is true also for chloride and sodium.

River discharge data show that the river neither gains nor loses water 

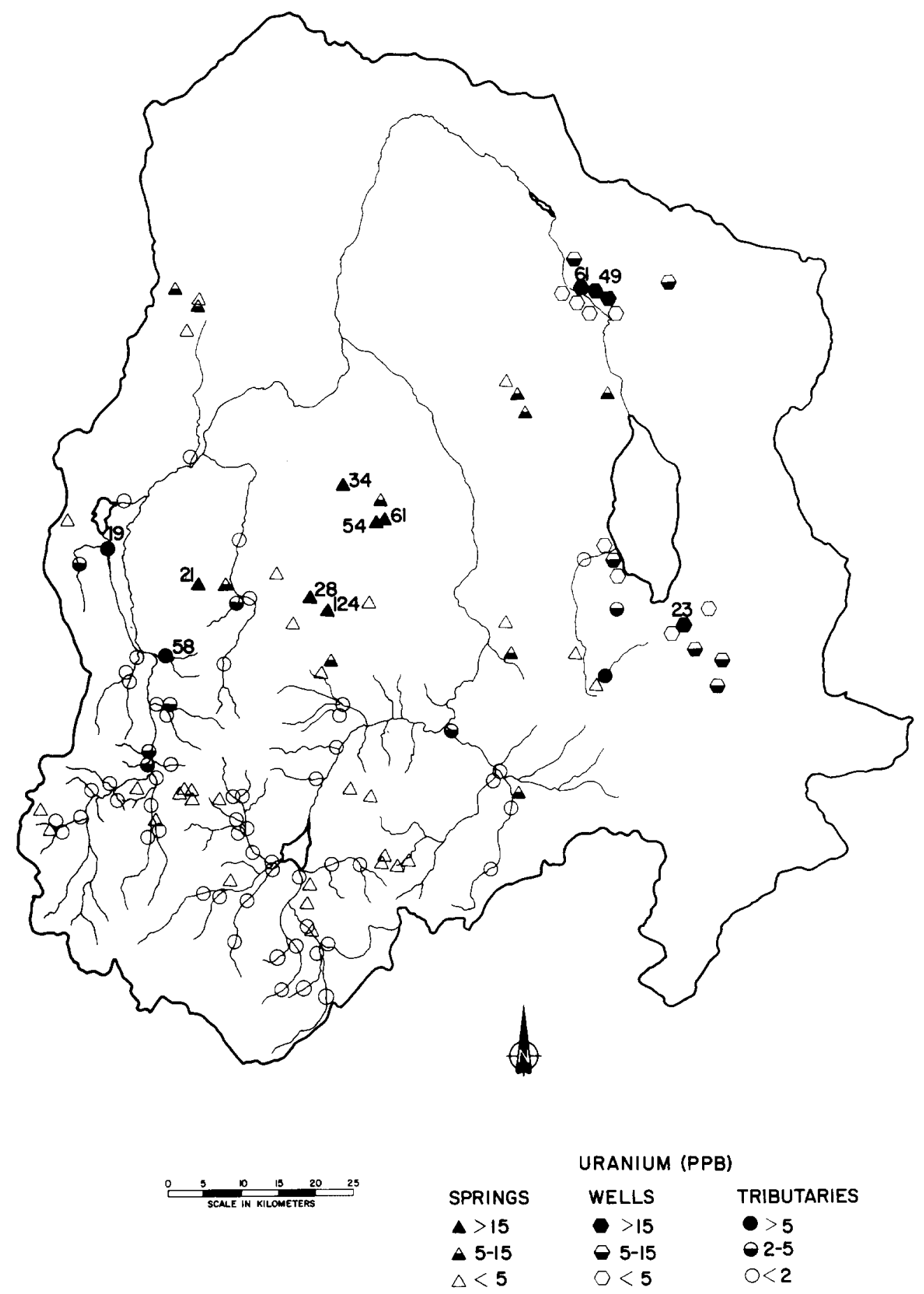

Fig. 5. Concentrations of uranium in well, spring and tributary waters. 


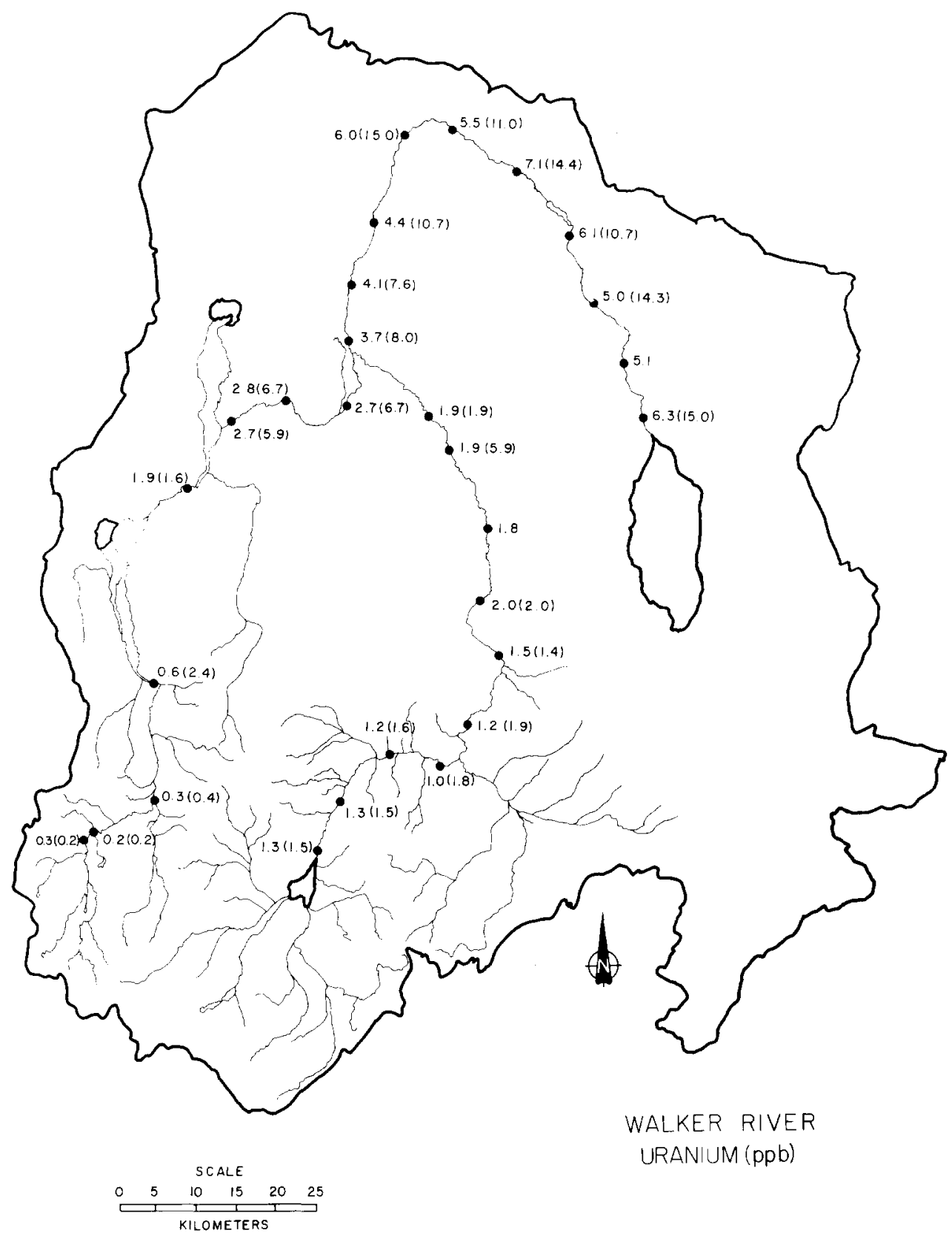

Fig. 6. Uranium concentrations in Walker River waters during June and (August).

during the high-flow period; whereas, during the low-flow period, water is lost from the system. During August the flow of water is maintained at an artificially high level by releases from the Bridgeport Reservoir. The gradual monotonic increase in uranium during both sampling periods suggests that 
- if high-uranium groundwater enters the East Fork - its flux is small compared to the flux of low-uranium Bridgeport water.

Uranium in the West Fork. From Topaz Reservoir to the point of convergence with the East Fork, the uranium concentration in the West Fork of the Walker River also shows an increase with distance of transport (Fig. 6). In the June samples, uranium increased from 0.6 to $2.7 \mathrm{ppb}$ and in August uranium increased from 2.4 to $6.7 \mathrm{ppb}$. However, these increases in uranium concentration are more irregular than those observed for the East Fork and appear to be related to areas under irrigation.

Uranium in the Walker River. In Mason Valley the East and West Forks merge to form the Walker River. Mason Valley encloses the Yerrington porphyry copper mine, situated on the west side of the river, and also a large irrigated area on the east side of the river. Below the confluence of the East and West Forks, the uranium concentration was found to be greater than the amount attainable by simple mixing of waters from both forks. Clearly, uranium is being added to the stream system at the southern end of Mason Valley. Uranium and other dissolved solids also show a gradual increase in concentration toward Walker Lake. For uranium the June increase is from 3.7 to $6.3 \mathrm{ppb}$, and the August from 8.0 to $15 \mathrm{ppb}$.

Plots of uranium, sodium and chloride versus flow distance (Figs. 7, 8, and 9) reveal some interesting trends:

(1) Concentrations generally increase with distance of transport.

(2) Concentrations increase at a slow rate in regions not heavily irrigated, i.e., the East Fork below the Bridgeport and Walker River below Wabuska.

(3) Concentrations increase sharply across heavily irrigated regions, i.e., Smith and Mason Valleys.
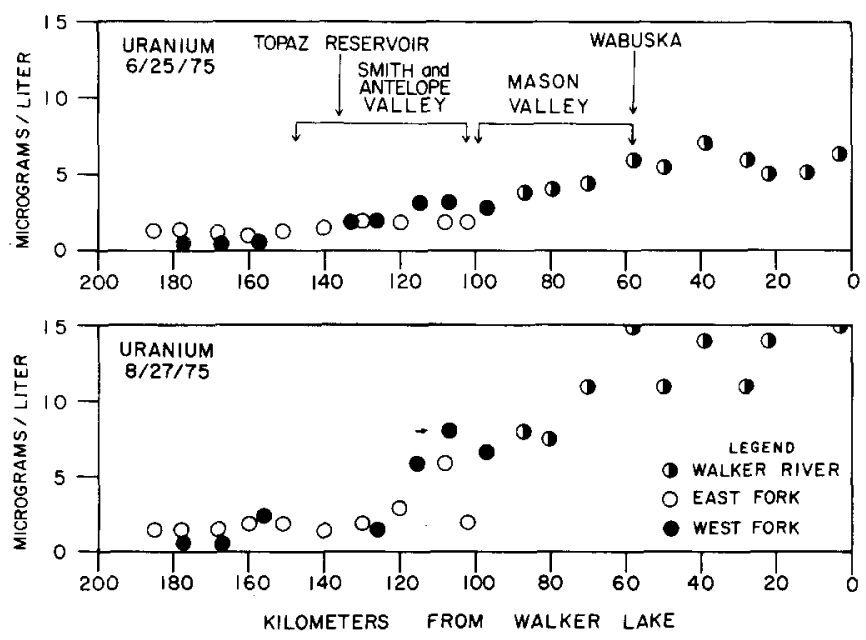

Fig. 7. Uranium versus flow distance for the Walker River and the East and West Forks. 

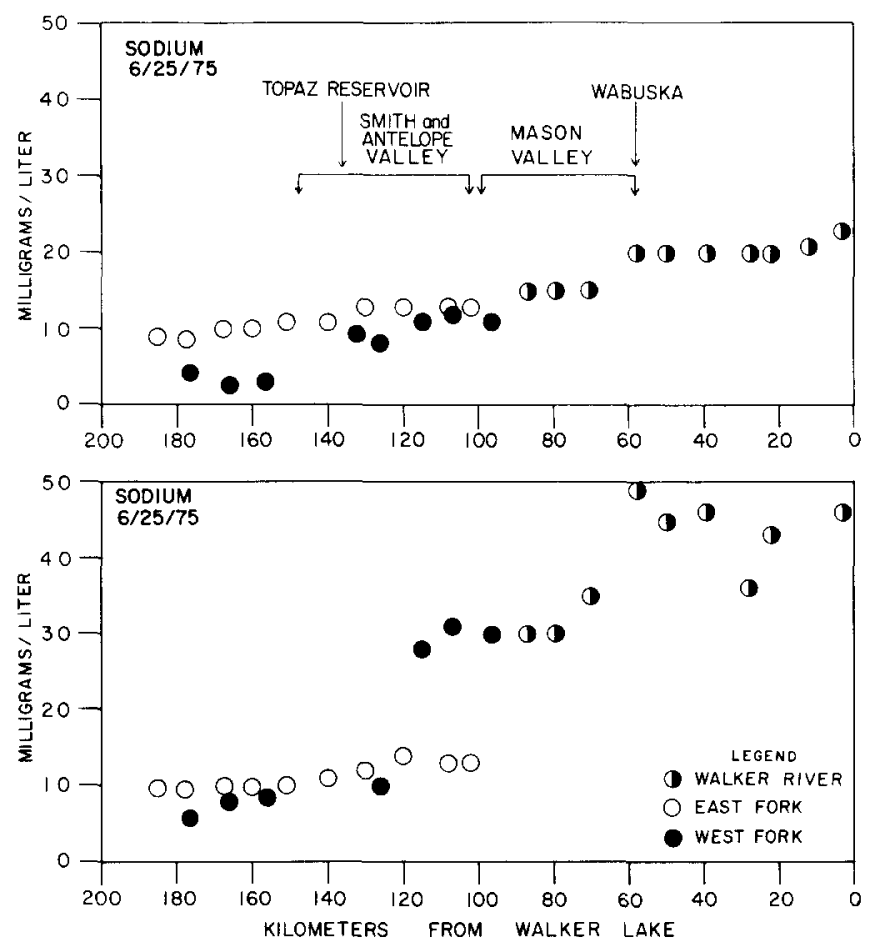

Fig. 8. Sodium versus flow distance for the Walker River and the East and West Forks.
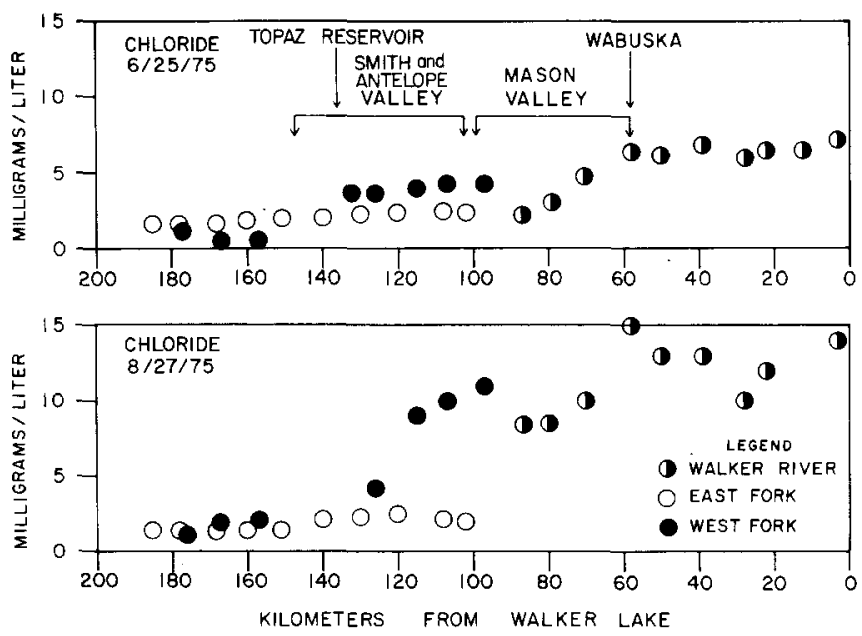

Fig. 9. Chloride versus flow distance for the Walker River and the East and West Forks. 
(4) Concentrations increase with decreased rate of flow, i.e., from June to August.

Plots of uranium/chloride versus flow distance (Fig. 10) show that in the Walker River and its East Fork uranium and chloride behave similarly. However, uranium/chloride ratios of samples taken from the West Fork indicate an increase of uranium relative to chloride above Topaz Reservoir. The uranium/chloride ratio decreases below the outfall of the reservoir and then increases to the point of confluence of both forks. There is also a subtle but consistent trend of increasing uranium relative to chloride for the Walker River in August.

In addition to uranium, sodium, and chloride, all other elements increase in concentration with a decrease in the flow rate (Fig. 11).

Uranium in Walker Lake. The terminal point of the Walker River system is Walker Lake. Since Walker Lake functions like a large evaporating pan, concentrations of most elements in the lake are considerably enhanced (Table II) relative to average river water. The lake has a high concentration of uranium $(130 \mathrm{ppb})$ compared to other large surface bodies of water and has a total uranium mass of $0.46 \times 10^{6} \mathrm{~kg}$. In contrast, Great Salt Lake contains only $5 \mathrm{ppb}$ uranium (Steward and Bentley, 1954).

Mass flux calculations. Calculations of the present-day mass fluxes of uranium, chloride and sodium were made for several sites on the Walker River system (Table III). Chloride is an extremely mobile element, i.e., saturation with chloride salt does not occur in the river system and chloride does not participate in sorption reactions; therefore, it can be used as a tracer. Sodium,
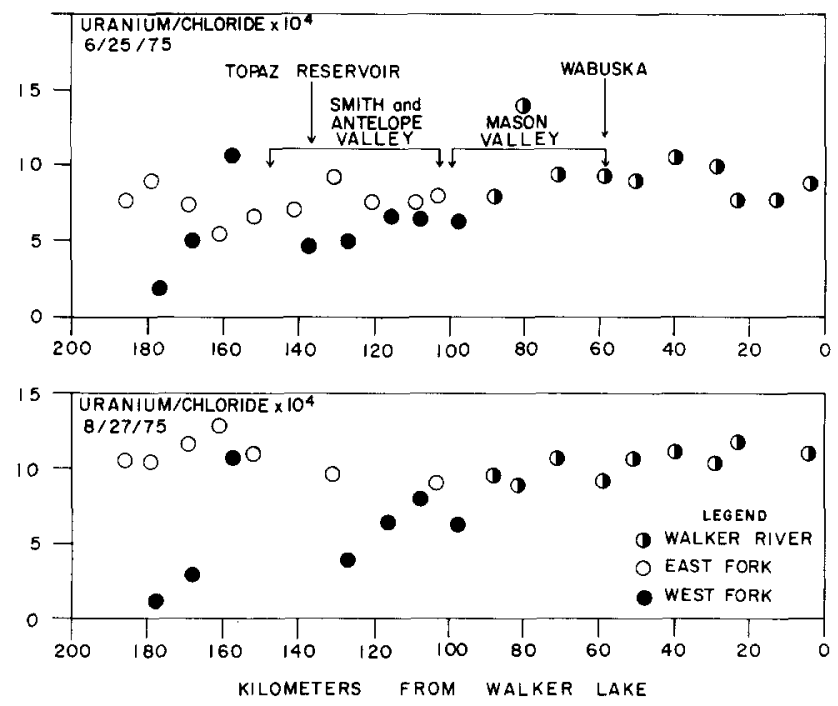

Fig. 10. Uranium/chloride ratios for the Walker River and the East and West Forks. 
CONCENTRATION (parts per million)
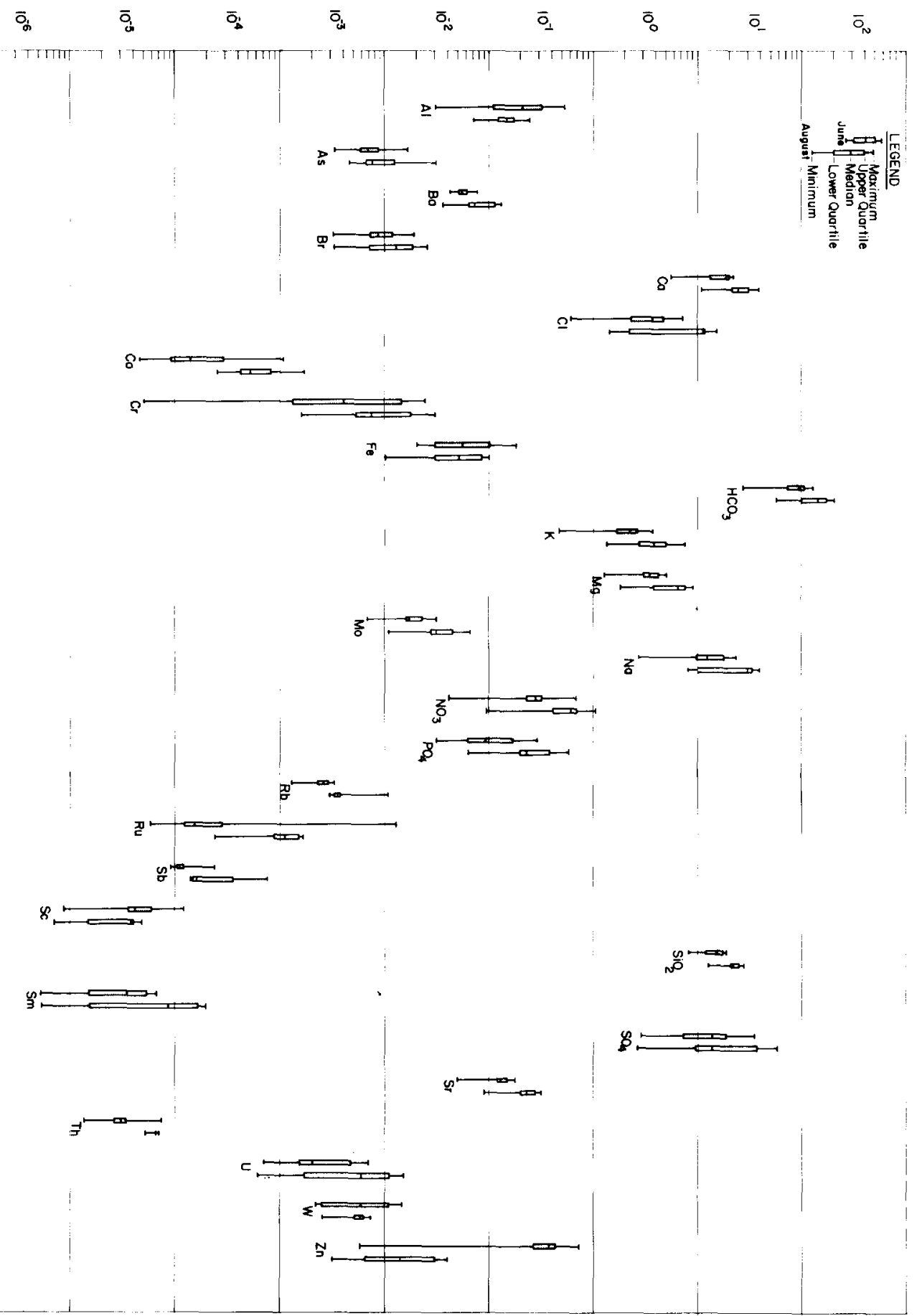

Fig. 11. Concentrations of selected chemical components for the Walker River and the East and West Forks. 
TABLE II

Comparison of Walker Lake and Walker River compositions (mg/l)

\begin{tabular}{lcc} 
& Walker Lake & Walker River* \\
\hline $\mathrm{HCO}_{3} * *$ & 2700 & 199 \\
$\mathrm{Cl}$ & 2200 & 12.5 \\
$\mathrm{SO}_{4}$ & 2020 & 45.7 \\
$\mathrm{Br}$ & 4.84 & 0.024 \\
$\mathrm{Na}$ & 3080 & 43.1 \\
$\mathrm{~K}$ & 163 & 7.73 \\
$\mathrm{Ca}$ & 13.3 & 34.4 \\
$\mathrm{Mg}$ & 157 & 8.21 \\
$\mathrm{SiO}$ & 0.05 & 24.5 \\
$\mathrm{Al}$ & 0.07 & 0.17 \\
$\mathrm{Sr}$ & 3.0 & 0.31 \\
$\mathrm{As}$ & 0.83 & 0.026 \\
$\mathrm{Ba}$ & 0.28 & 0.091 \\
$\mathrm{Mo}$ & 0.73 & 0.052 \\
$\mathrm{Cu}$ & 0.005 & 0.005 \\
$\mathrm{U}$ & 0.130 & 0.014 \\
$\mathrm{PO}-\mathrm{P} * * *$ & 0.54 & 0.16 \\
$\mathrm{NO}_{3}$ & 0.13 & 0.22 \\
\hline
\end{tabular}

*Site 3; sampled August 27, 1975.

**Total alkalinity reported as bicarbonate.

***Orthophosphate reported as the element phosphorous.

on the other hand, is chemically reactive and may participate in sorption and dissolution/precipitation processes in the Walker River system.

A summary of changes in mass flux across Mason Valley is also given in Table III. Because tributary flow data are not available, these calculations were not made for other upstream regions. The calculations indicate:

(1) In June stream discharge decreases downstream along the West Fork and the Walker River. On the East Fork, discharge increases slightly between Bridgeport and Sweetwater and then decreases from Sweetwater to Mason.

(2) In August downstream discharge along both forks first increases then decreases. Walker River discharge decreases sharply across Mason Valley.

(3) In June the flux of each element as well as the total salt load increases in a downstream direction along both forks and the Walker River.

(4) In August the flux of each element and the total salt load either increases or remains the same along both forks. However, with the exception of uranium, the opposite effect is observed across Mason Valley.

In order to calculate the mass fluxes of uranium and chloride into Walker Lake and the subsequent distribution of uranium between lake-bottom sediment and overlying lake water, the average pre-European uranium and chloride contents and discharge rate of the Walker River must be estimated. 


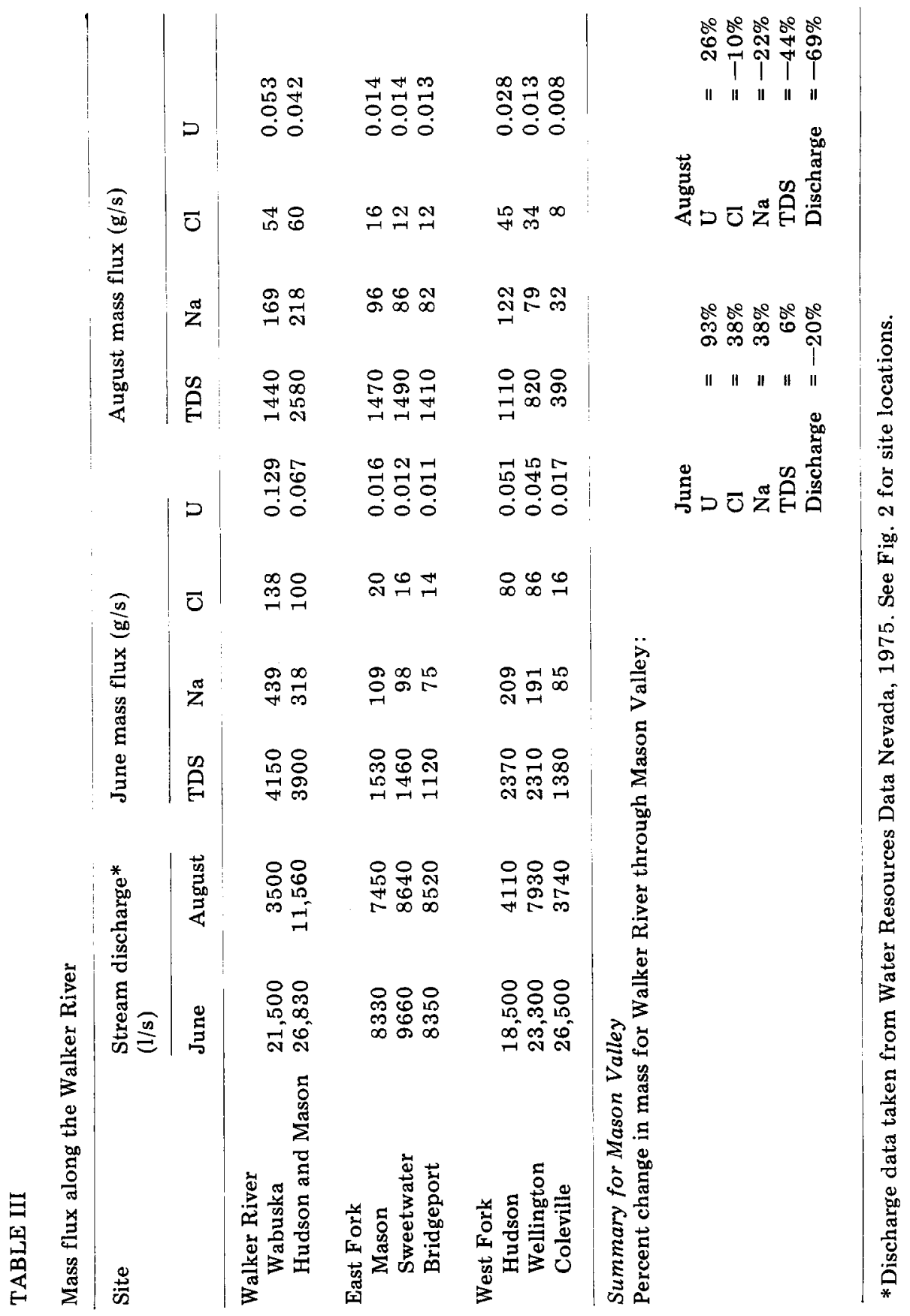


In addition, the present-day volume of Walker Lake must be known.

Benson (1978) has recently shown that Walker Lake desiccated during the period 9050-6400 years B.P. and probably did not begin receiving significant discharge from the Walker River again until 5000 years B.P. The average flux of river water during this period of time is equal to the evaporation flux minus the precipitation flux. The average mass fluxes of uranium and chloride are then given by the fluid flux multiplied by the average uranium and chloride concentrations of river water.

Present-day values of the precipitation rate, the evaporation rate and the uranium and chloride concentrations are available and can be considered representative of past conditions. Unfortunately, most of the uranium and chloride data acquired in this study were contaminated or artificially concentrated by agriculturally-linked evaporative processes. Only two upstream stations on the West Fork, stations 64 and 71 (Fig. 4), are considered reasonable estimators of pristine water. To check the validity of these estimators, the sodium and chloride contents of 24 creeks in the Lake Tahoe watershed (J.C. Brown and C.M. Skau, unpublished data) were compared with the West Fork data. The results of the comparison were quite favorable (chloride was the same in both systems and sodium differed by only 10\%); therefore data from the West Fork were used to assign chloride and uranium concentrations to both the high and low flow regimes. In addition, the volume flux was seasonally weighted $(80 \%$ of the flow was assumed to occur in the high-flow period).

The evaporation and precipitation flux, estimated from pre-historical lake level data (Benson, 1978) and a surface area-lake level curve, operates on an average lake surface. Graphical integration yielded an average lake level of $1236 \mathrm{~m}$ which corresponds to an average surface area of $241 \mathrm{~km}^{2}$.

The results of the mass flux calculations (Table IV) indicate that only $16 \%$ of the chloride present in Walker Lake has been contributed by the Walker River. The other $84 \%$ is apparently due to upward diffusion of chloride across the sediment-water interface (see fig. 10 of Benson, 1978). However, the uranium in Walker Lake represents about $50 \%$ of the total uranium flux from the Walker River. The other $50 \%$ has been lost to the sediment either through sorption or precipitation processes. This conclusion is supported by uranium concentration profiles of fluids extracted from gravity cores (Fig. 12). In all cases, uranium in solution decreases with depth - suggesting its transfer from the fluid to the sediment.

Statistical correlations. Sediment samples were collected at 23 sites during the August water sampling. A plot of water and sediment uranium concentrations (Fig. 13) shows that there is little correlation between the concentration of uranium in sediment and river water.

Cross-correlation coefficients were computed on log transformed and normalized spring and tributary data. Molybdenum was the only element highly correlated with uranium. The cross-correlation coefficient was 0.89 for the tributary waters and 0.85 for the spring waters. 


\section{TABLE IV}

Summary of mass flux calculations

\section{Data}

Average elevation of Walker Lake for the last 5000 years

$=1235 \mathrm{~m}$

Average surface area of Walker Lake for the past 5000 years

$=241 \mathrm{~km}^{2}$

Average evaporation rate on Walker Lake*

Average precipitation rate on Walker Lake**

$=1.27 \mathrm{~m} / \mathrm{yr}$

$\mathrm{Cl}$ concentration in Walker River (low flow)

$=0.10 \mathrm{~m} / \mathrm{yr}$

$\mathrm{Cl}$ concentration in Walker River (high flow)

$=\quad 2.2 \mathrm{mg} / \mathrm{l}$

$\mathrm{U}$ concentration in Walker River (low flow)

$=0.6 \mathrm{mg} / 1$

$\mathrm{U}$ concentration in Walker River (high flow)

$=\quad 1.6 \mathrm{mg} / \mathrm{l}$

$\mathrm{Cl}$ concentration in precipitation***

$\mathrm{U}$ concentration in precipitation

Volume of Walker Lake

$=\quad 0.5 \mathrm{mg} / 1$

$\mathrm{Cl}$ concentration in Walker Lake

$=0.10 \mathrm{mg} / 1$

$=0 \mathrm{mg} / \mathrm{l}$

$\mathrm{U}$ concentration in Walker Lake

$=3.53 \times 10^{12} 1$

$=2250 \mathrm{mg} / \mathrm{l}$

$=0.130 \mathrm{mg} / \mathrm{l}$

\section{Results}

Mass of $\mathrm{Cl}$ input to Walker Lake by Walker River (5000 years) $\quad=1.2 \times 10^{15} \mathrm{mg}$

Mass of U input to Walker Lake by Walker River (5000 years) $\quad=1.0 \times 10^{12} \mathrm{mg}$

Mass of $\mathrm{Cl}$ in Walker Lake

Mass of U in Walker Lake

$=7.9 \times 10^{15} \mathrm{mg}$

$=0.46 \times 10^{12} \mathrm{mg}$

*Harding (1965)

**Composite data from three weather stations located at Hawthorne, Nevada.

***Brown and Skau (1975).

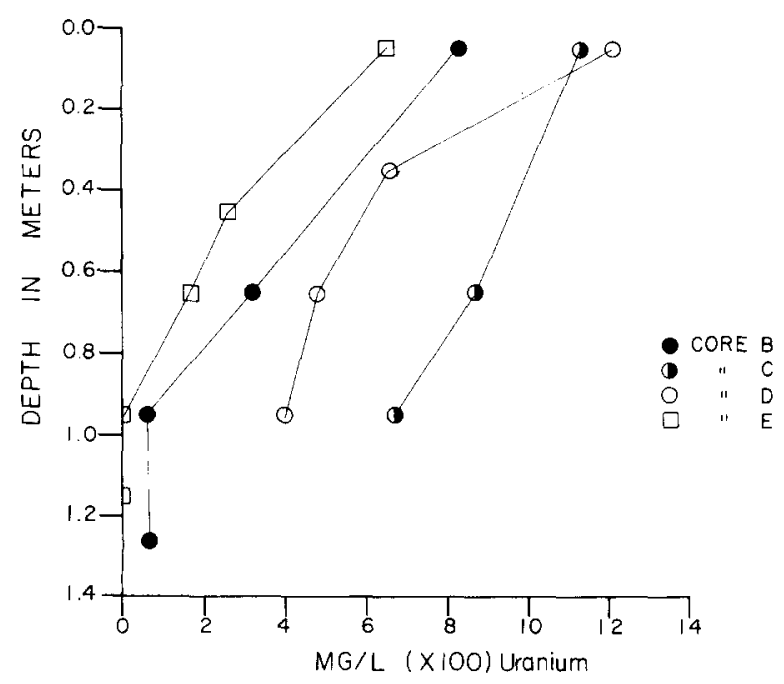

Fig. 12. Uranium concentration in Walker Lake pore fluids. 


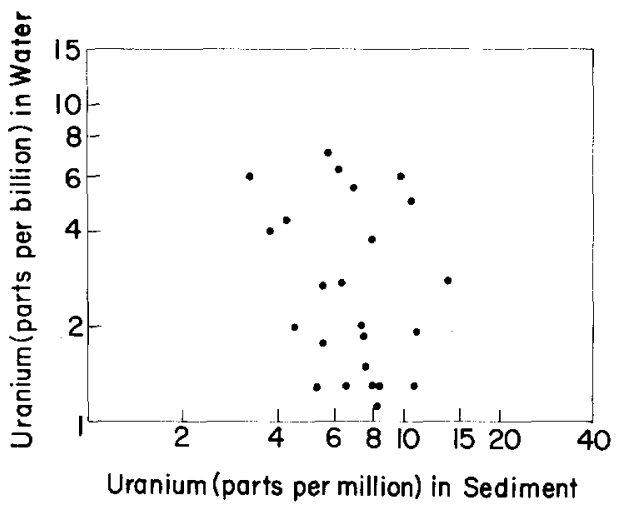

Fig. 13. Uranium in water versus uranium in sediment in the Walker River, including the East and West Forks.

\section{DISCUSSION}

\section{Uranium transport}

This study provides insight into processes which govern the leaching, transport and deposition of uranium in closed basins of the Intermontane West. Snowmelt recharges the surface and groundwater systems in late spring. Ephemeral springs and intermittent streams act as conduits for this acidic water, which leaches mineral surfaces releasing uranium and other elements.

The locations of springs and tributary systems are in many cases structurally controlled. The same structure governed the circulation of earlier uranium-depositing hydrothermal solutions. Analyses of water samples from tributaries and springs are, therefore, useful in locating uranium anomalies located along permeable fracture and fault surfaces. In this study, such data indicated the presence of high concentrations of uranium in the central and west-central portions of the Walker Basin (Fig. 5).

In the Walker Basin, agricultural practices strongly influence the concentration of uranium in the Walker River and its East and West Forks. Irrigation practices induce significant losses of fluid through evaporation and evapotranspiration processes. This results in artificial increases in concentration of uranium and other elements (Figs. 6, 7, 8 and 9).

Changes in reservoir storage also act to complicate the pattern of uranium transport. For example, release of low-uranium water from the Topaz Reservoir apparently caused the concentration of uranium in the West Fork to decrease and the uranium/chloride ratio to sharply increase during the month of August (Figs. 6, 7 and 10).

Artificial regulation of storage can also mask the presence of uranium anomalies. During late August, flow along the East Fork would be exceedingly small under natural conditions; and if the groundwater/runoff ratio were high enough, the discharge of uranium-rich groundwater into the river 
system would be detectable. However, flow along the East Fork in August was artificially maintained at a value nearly equivalent to the June rate (Table III), and known uranium deposits (Fig. 2) were not detected (Fig. 6).

Agricultural practices also induce significant changes in the masses of fluid and dissolved solids transported by the Walker River. In Mason Valley, irrigation ties up a considerable portion of the June (20\%) and August (70\%) discharges. Most of this water is not returned to the river but is lost to evaporation and evapotranspiration processes. Huxcel (1969) has calculated that $45 \%$ of the water contributed to Mason Valley from 1948 to 1965 was lost to storage and evaporation.

The mass of uranium dissolved in the Walker River increases through Mason Valley in both June and August, even though the mass of water decreases (Table III). Uranium-bearing $(33 \mathrm{ppm})$ phosphate fertilizers were considered a potential source for the additional uranium; however, calculations showed that unreasonable amounts of fertilizer $(164,000 \mathrm{~kg} /$ day and $28,800 \mathrm{~kg} /$ day) would have had to be added in June and August respectively to account for the observed increase.

Uranium analyses of water samples taken from wells bottomed in Pleistocene lake sediments indicated relatively high uranium concentrations (Fig. 5). This suggests that lake sediments are a source of mobile uranium and that in Mason Valley uranium may be added to the river system by the leaching of Pleistocene lake sediments by oxygen-rich irrigation waters, which react with precipitated or sorbed forms of U(IV) changing it to the more easily complexed U(VI) form.

Another possibility is that uranium minerals associated with the Yerrington copper deposit are a source of the mobile uranium. However, at this time it is not possible to clearly determine if either of these potential sources are indeed responsible for the observed increase in the mass of dissolved uranium.

The terminal point of the transport system (Walker Lake) has acted as a sink for uranium and other dissolved solids for the past 5000 years. Of the one million kilograms of uranium transported to the lake during this time nearly $50 \%$ still remains in solution. The residence time $(\tau)$ for uranium in Walker Lake is given By:

$\tau=\frac{M_{\mathrm{u}, 1}}{\mathrm{~d} M_{\mathrm{u}, \mathrm{r}} / \mathrm{d} t}$

where $\tau=$ the residence time in lake water; $M_{\mathrm{u}, 1}=$ the mass of uranium in the lake water; and $\mathrm{d} M_{\mathrm{u}, \mathrm{r}} / \mathrm{d} t=$ the mass of uranium introduced to the lake by the river per unit time.

From the data of Table IV, the residence time of uranium is calculated to be approximately 2500 years. The reason for the long residence time and the reason for the conservative character of uranium transport in the Walker River system lies in the fact that both lake and river waters contain nearly 
8 ppm $\mathrm{O}_{2}$ and considerable amounts of carbonate (Table II). The combination of oxidizing conditions and neutral or negatively charged uranyl carbonate complexes (see Langmuir, 1978) keep the uranium from sorbing onto negatively charged surfaces and from precipitating. However, diffusional transport across the sediment-water interface brings the uranium into contact with pore fluids characterized by an Eh range of - -0.60 to -0.14 volt (unpublished data of L.V. Benson). Reduction of the uranium ion from the U(VI) to the U(IV) state allows the formation of uraninite $\left(\mathrm{UO}_{2}\right)$ and/or coffinite $\left(\mathrm{USiO}_{4}\right)$ and may be the explanation for the decreasing pore fluid concentration of uranium with depth (Fig. 12).

\section{Uranium accumulation}

If it is assumed that the present-day uranium accumulation rate is typical of former accumulation rates and that transport has occurred for the past two million years, a calculation shows that $4 \times 10^{8} \mathrm{~kg}$ of uranium would have been transported to the terminal point of the Walker River system.

This calculation is admittedly crude. The interconnection of lakes during the Pleistocene would have facilitated the even distribution of dissolved uranium among the nine basins of the Lahontan system (Benson, 1978); in addition, the effects of climatic change on leaching and transport rates are not known. However, the calculation serves to indicate that closed basin termini can be sites for significant uranium accumulation and may represent potential sites of uranium ore deposits.

\section{CONCLUSIONS}

Detection of anomalies and application to wide-spread reconnaissance surveys. The results of this study show that widely-spaced water samples (approximately one site per $10-20 \mathrm{~km}^{2}$ ) can, under appropriate hydrologic conditions, be used to detect areas of anomalous uranium concentrations. Specific conclusions are:

(1) Analyses of water samples from tributaries and springs are useful in locating uranium anomalies associated with fault and fracture surfaces.

(2) The optimum time for sampling occurs after the peak of snowmelt runoff but before flow along smaller tributaries ceases.

Effects of agriculture. The data clearly show that agriculturally linked processes cause changes in the mass and concentration of uranium along the East and West Forks and the Walker River. These changes are so extreme that they mask the presence of known uranium deposits and render impossible the unequivocal detection of unknown deposits.

Uranium transport. Snowmelt recharges the surface and subsurface hydrologic systems in the period April through August. The acidic water reacts 
with mineral surfaces releasing uranium to the fluid system. Uranium in the $\mathrm{U}(\mathrm{VI})$ state is an extremely mobile component and apparently is not removed by interaction with river sediment. The residence time of uranium in Walker Lake is on the order of 2500 years. Reduction processes which operate beneath the sediment-water interface cause the slow transfer of uranium from pore fluids to minerals. It is not known if the transfer is caused by sorption or precipitation processes.

Formation of ore deposits. Approximately $200 \mathrm{~kg}$ of uranium is annually transported to the terminal point of the Walker River system. Over many thousands of years, the accumulation of uranium can be significant and may lead to the formation of ore deposits.

\section{ACKNOWLEDGEMENTS}

We would like to express appreciation to Pat Harris of the University of Nevada and to the Nuclear Chemistry staff at the Lawrence Livermore Laboratory for chemical analyses. K.P. Puchlik, J. Donnelly, and R. Garrels provided many thoughtful comments. Drafting was provided by P. Proctor. This study was conducted as part of the National Uranium Resource Evaluation (NURE) program sponsored by the United States Department of Energy.

\section{REFERENCES}

Benson, L.V., 1978. Fluctuations in the level of Glacial Lake Lahontan during the last 40,000 years. Quat. Res., 9: 300-318.

Brown, J.C. and Skau, C.M., 1975. Chemical composition of snow in the east central Sierra Nevada. Nev. Desert Res. Inst., Coop. Rep. Ser., AG-1: 13 pp.

Cupp, G.M., Leedon, S.H., Mitchell, T.P., Kiloh, K.D. and Horton, R.C., 1977. Preliminary study of the favorability for uranium in selected areas in the Basin and Range province, Nevada. Bendix Field Eng. Corp., GJBX-74 (77): 62 pp.

Domenico, D.A., Schulke, D.F. and Maxey, B.S., 1966. Physical and economical aspects of conjunctive use of irrigation water in Smith Valley, Lyon County, Nevada. Nev. Desert Res. Inst., Tech. Rep., 1: 47 pp.

Garside, L.J., 1973. Radioactive mineral occurrences in Nevada. Nev. Bur. Mines Geol., Bull, $81: 121 \mathrm{pp}$.

Gilbert, C.M. and Reynolds, M.W., 1973. Character and chronology of basin development, western margin of the Basin and Range province. Geol. Soc. Am. Bull., 84: 2489-2510.

Harding, S.T., 1965. Recent variations in the water supply of the western Great Basin. Water Resour. Cent. Arch., Univ. Calif., Berkeley, Arch. Ser. Rep., 16: 226 pp.

Huxcel, C.J., 1969. Water resources and development in Mason, Lyon and Mineral Counties, Nevada, 1948-1965. Nev. Div. Water Resour. Bull., 38: 77 pp.

Langmuir, D., 1978. Uranium solution-mineral equilibrium at low temperatures with applications to sedimentary ore deposits. Geochim. Cosmochim. Acta, 42: 547-569.

Moore, J.A., 1969. Geology and mineral deposits of Lyon, Douglas, and Ormsby Counties, Nevada. Nev. Bur. Mines Geol., Bull., 75: 44 pp. 
Ross, D.C., 1961. Geology and mineral deposits of Mineral County, Nevada. Nev. Bur. Mines Geol., Bull., 58: 98 pp.

Staatz, M.H. and Bauer, H.L., 1953. Uranium in the east Walker area, Lyon County, Nevada. U.S. Geol. Surv., Bull., 988-C: 17 pp.

Steward, D.C. and Bentley, W.C., 1954. Analysis of uranium in sea water. Science, 120 : $50 \mathrm{pp}$.

UCID-16911-P-1, 1976. Hydrogeochemical and Stream Sediment Survey (NURE). Preliminary Report on the Walker River Basin Study. Lawrence Livermore Laboratory, Livermore, Calif., 104 pp.

Vasey, B.J. and Hastings, G.C., 1974. Alternative plans for water resource use, Walker River Basin Area. Rep. Nev. Div. Water Resour., State Eng. Office, 75 pp.

Water Resources Data for Nevada (1958-1977). U.S. Geol. Surv. Water Data Rep., Nev. Ser. 